\title{
Perkiraan Umur Lelah Struktur Kapal Berbasis Keandalan dengan Metode Mean Value First Order Second Moment
}

\author{
M. Nurul Misbah ${ }^{\left.1)^{*}\right)}$, Dony Setyawan ${ }^{1)}$, Ahmat Soleh ${ }^{1)}$ \\ ${ }^{1)}$ Departemen Teknik Perkapalan, Institut Teknologi Sepuluh Nopember \\ Jl. Raya ITS, Sukolilo, Surabaya, Indonesia 60111
}

diajukan pada $: 16 / 05 / 19 \quad$ direvisi pada $: 21 / 06 / 19 \quad$ diterima pada $: 29 / 07 / 19$

\begin{abstract}
Abstrak
Desain berbasis keandalan sering digunakan dalam perancangan struktur yang mempunyai ketidakpastian harga dari parameter, baik parameter kekuatan struktur maupun parameter beban operasional. Pendekatan desain berbasis keandalan lebih realistis dibanding dengan pendekatan faktor keamanan untuk mengakomodasi ketidakpastian tersebut. Salah satu metode untuk menghitung keandalan struktur yang efisien adalah metode Mean Value First Order Second Moment (MVFOSM). Dalam paper ini akan dibahas perkiraan umur lelah struktur kapal berbasis keandalan, khusunya pada sambungan pelat alas pada midship kapal. Dengan menyatakan keandalan sebagai fungsi waktu maka peluang aman dari struktur tersebut pada waktu tertentu dapat diketahui. Studi kasus diambil pada kapal tanker 17.500 DWT yang dioperasikan di perairan Masalembo. Akibat fabrikasi pada pelat alas kapal diasumsikan terjadi retak permukaan sedalam 0,5 mm. Dengan menggunakan metode MVFOSM didapat bahwa nilai keandalan kapal dengan nilai rentang tegangan $(\Delta \sigma)$ rata-rata sebesar 25,63 MPa dengan COV 0,416, dan tegangan rata-rata $\left(\sigma_{\text {mean }}\right)$ sebesar 47,81 MPa, struktur kapal tanker dianggap cukup andal sampai tahun ke-18 dengan indeks keandalan 3,65 atau peluang aman sebesar $99,8 \%$
\end{abstract}

Copyright $@ 2019$, KAPAL, 1829-8370 (p), 2301-9069(e)

Kata Kunci : Keandalan, Struktur kapal, Mean Value First Order Second Moment (MVFOSM), Retak.

\section{PENDAHULAN}

Dalam desain struktur kapal perlu diperhatikan adanya karakter ketidakpastian dari beberapa parameter desain kapal, seperti beban gelombang, sifat material, dan proses produksi. Dalam desain struktur kapal, ketidakpastian ini biasanya diantisipasi dengan memberikan faktor keamanan. Penggunaan kriteria ini mungkin dapat menyebabkan overdesigning struktur atau bahkan lebih buruk dari itu, yaitu underdesigning yang menyebabkan perkiraan keamanan yang tidak sesuai, sehingga terjadi kegagalan pada struktur.

Untuk itu diperlukan pendekatan kriteria desain dan metode analisis yang memperhitungkan keacakan, baik beban maupun

*) Penulis Korespondensi :

Email : mnmisbah@na.its.ac.id sifat struktur untuk memperkirakan resiko dari respon yang tidak bisa diterimanya. Berdasarkan metode ini, desain struktur kapal akan cenderung lebih rasional dan mengarah pada prosedur desain berbasis probabilitas yang mengacu pada desain limit states, yang berdasar pada filosofi desain berbasis keandalan.

Teori keandalan struktur menitikberatkan pada penilaian ketidakpastian-ketidakpastian dan metode-metode pengklarifikasi serta rasionalisasi dalam proses perancangan untuk mendapatkan nilai peluang struktur tersebut memenuhi tujuan perancangan dalam kondisi tertentu [1].

Metode MVFOSM adalah salah satu metode yang dipakai untuk memperkirakan keandalan komponen yang tidak dibuat secara masal, artinya keandalan komponen tidak diperoleh secara reliability life-testing, namun diperkirakan 
langsung dengan memperhatikan fungsi kerapatan peluang perubah-perubah acak yang mengatur perilaku kegagalan tersebut dan metode ini lazim dipakai dalam analisa keandalan struktur [2].

Metode lain yang hampir sama dengan MVFOSM adalah First Order Reliabilty Method (FORM). Kedua metode ini sama-sama menggunakan orde pertama dari deret Taylor. Perbedaan kedua metode ini adalah pada tempat linierisasi fungsi batas. Pada MVFOSM linierisasi dilakukan pada harga rata-rata variabel, sedangkan pada FORM linierisasi dilakukan pada satu tempat sebarang pada batas kegagalan [3].

Honarmandi telah melakukan optimisasi balok kantilever berbasis keandalan dengan menggunakan metode MVFOSM dan FORM. Penggunaan MVFOSM dan FORM menunjukkan hasil yang hampir sama. Hanya ada sedikit perbedaan pada keduanya untuk keandalan yang tinggi [4].

Hasil yang sama pada penggunaan metode MVFOSM dan FORM juga ditunjukkan oleh Liu dalam optimisasi struktur suspensi misil berbasis keandalan [5].

Tujan dari penelitian ini adalah untuk memperkirakan keandalan struktur pada umur kapal tanker 17.500 DWT dengan metode MVFOSM.

\section{METODE}

Penelitian ini didasarkan pada studi kasus yang dilakukan pada kapal tanker 17.500 DWT yang beroperasi pada perairan Masalembo. Adapun data ukuran utama kapal adalah panjang antar sumbu tegak $154 \mathrm{~m}$, sarat $7 \mathrm{~m}$, lebar $26,8 \mathrm{~m}$, dan tinggi $11,5 \mathrm{~m}$.

Kapal yang terapung di laut dalam kondisi sagging dapat dasumsikan sebagai balok [6] yang ditumpu pada kedua ujungnya, dan dalam kondisi hogging diasumsikan sebagai balok yang ditumpu pada bagian tengah. Kedua kondisi ini menghasikan momen bending vertikal maksimum di daerah sekitar tengah kapal.

Tegangan maksimum yang terjadi akibat momen bending ini terletak pada bagian struktur yang jauh dari sumbu netral, dalam hal ini adalah pelat geladak dan pelat alas. Pada kondisi sagging tegangan tarik terjadi pada pelat alas dan tegangan tekan terjadi pada pelat geladak. Sedangkan pada kondisi hogging tegangan tarik terjadi pada pelat geladak dan tegangan tekan terjadi pada pelat alas. Kedua bagian ini berpotensi besar terjadi kegagalan, termasuk kegagalan akibat kelelahan.

Apabila terdapat retak pada bagian alas, misalnya retak permukaan, maka akibat tegangan tarik-tekan yang berulang retak ini akan merambat sampai kedalaman retak sama dengan kedalaman retak kritis. Jika faktor intensitas tegangan lebih besar dari pada harga fracture toughness material maka retak tersebut merambat dengan sangat cepat dan terjadi kepecahan.

Jika kedalam retak kritis lebih besar dari pada tebal pelat alas, maka retak akan terus merambat sampai kedalaman retak sama dengan ketebalan pelat, dan retak permukaan berubah menjadi trough thickness crack. Kondisi ini akan menyebabkan terjadinya kebocoran, karena pelat alas berhubungan langsung dengan air laut.

Hal serupa juga terjadi pada pelat geladak, hanya saja kemungkinan terjadi kebocoran pada pelat geladak lebih kecil karena tidak berhubungan langsung dengan air laut.

Pada kasus ini penentuan umur lelah didasarkan pada perambatan retak permukaan yang terjadi pada pelat alas bagian tengah kapal. Retak awal akibat proses produksi diasumsikan sebesar 0,5 mm, yaitu sebesar kemampuan maksimum ultrasonic test.

Akibat tegangan tarik dan tekan yang berulang-ulang, retak ini merambat sampai kedalaman retak sama dengan retak kritis atau sampai kedalaman retak sama dengan ketebalan pelat alas. Kondisi ini didefinisikan sebagai batas umur lelah struktur kapal.

Tegangan tarik dan tekan dihitung berdasarkan kondisi gelombang yang terjadi di perairan Masalembo. Data yang digunakan adalah data tinggi gelombang rata-rata bulanan selama lima tahun yang diambil dari data Badan Meteorologi dan Geofisika Maritim Surabaya. Tinggi gelombang dan konstanta persamaan perambatan retak dan rentang tegangan dianggap sebagai variabel probabilistik, sedang kondisi kapal diasumsikan tetap even keel pada sarat muatan penuh. Dari perhitungan ini akan dapat diketahui seberapa besar indeks keandalan struktur kapal pada waktu tertentu

\subsection{Permodelan Beban Gelombang}

Menurut Bhattacharrya [7] momen bending yang terjadi pada kapal terdiri dari tiga komponen, yaitu momen bending yang disebabkan perbedaan distribusi berat dan gaya tekan ke atas ketika diam di air tenang, momen bending yang disebabkan karena gelombang yang terbentuk akibat gerak kapal di air tenang, dan momen bending yang disebabkan karena kapal berada di laut bergelombang, yang terdiri dari momen bending selama heaving dan momen bending selama pitching. sebesar

Momen bending selama heaving adalah 


$$
\begin{array}{r}
B M=\int\left\{\int\left[w(x) \pm \frac{w^{\prime}}{g}(x) \omega^{2} z_{a}\right] d x\right\} d x \\
-\int\left\{\int[\rho g A(x)] d x\right\} d x \\
\pm \int\left\{\int\left[2 \rho g y(x) z_{a}\right] d x\right\} d x
\end{array}
$$

di mana $w$ adalah berat kapal $\omega$ adalah frekuensi heaving, $z_{a}$ adalah amplitudo heaving, $\rho$ adalah massa jenis air laut, $g$ adalah percepatan gravitasi, $A$ dan $y$ adalah amplitudo gelombang.

Sedangkan momen bending selama pitching adalah sebesar

$$
\begin{aligned}
& =\int\left\{\int\left[w(x) \pm \frac{w^{\prime}}{g}(x) x \frac{d^{2} \theta}{d t^{2}}\right] d x\right\} d x \\
& -\int\left\{\int[\rho g A(x)] d x\right\} d x \\
& \pm \int\left\{\int[2 \rho g x \theta y(x)] d x\right\} d x
\end{aligned}
$$

dimana $\theta$ adalah amplitudo sudut pitching.

\subsection{Kelelahan Pada Struktur Kapal}

Salah satu modus kegagalan pada struktur kapal adalah kegagalan akibat kelelahan. Kelelahan terjadi akibat tegangan fluktuatif tarik dan tekan yang terjadi pada struktur kapal, disebabkan oleh gelombang yang mengenai badan kapal. Fluktuasi tegangan ini dapat menimbulkan retak mikroskopik yang makin lama makin besar hingga akhirnya terjadi kepecahan atau kapal mengalami kebocoran akibat retak yang kedalamannya sama dengan tebal pelat.

Biasanya umur fatigue dari suatu komponen yang dikenai beban fluktuatif didefinisikan sebagai jumlah siklus tegangan yang dibutuhkan sampai terjadinya retak awal ditambah dengan jumlah siklus tegangan yang menimbulkan perambatan retak sampai terjadi kegagalan.

Dalam penelitian ini diasumsikan retak awal sudah terjadi, sehingga umur lelah total sama dengan siklus yang dibutuhkan untuk perambatan retak sampai sebesar kedalaman retak kritis atau sama dengan tebal pelat. Laju perambatan retak sebanding dengan stress range, dan biasa dinyatakan dengan intensitas tegangan $\Delta K$, yang merupakan fungsi dari besarnya tegangan, ukuran dan geometri retak, dan geometri struktur [8]. Persamaan dasar perambatan retak biasanya dinyatakan dalam bentuk Hukum Paris, sebagai berikut.

$$
\frac{d a}{d N}=C(\Delta K)^{m}
$$

dimana $a$ adalah perambatan retak, $N$ jumlah siklus, $\Delta K$ adalah rentang faktor intensitas tegangan, $C$ dan $m$ adalah konstanta material. Sedangkan $\Delta K$ bisa dituliskan dengan persamaan berikut:

$$
\Delta K=\alpha \Delta \sigma \sqrt{\pi}
$$

dimana $\alpha$ adalah faktor geometri retak.

Untuk beban fluktuatif dengan rasio tegangan minimum dan tegangan maksimum positif ada koreksi Hukum Paris [8]sebagai berikut:

$$
\frac{d a}{d N}=\frac{C(\Delta K)^{m}}{(1-R)^{0,5}}
$$

dimana $R$ adalah rasio teganagan minimum dan tegangan maksimum.

Jika stress range bervariasi maka menurut Miner [9] umur fatigue total adalah penjumlahan umur fatigue pada masing-masing stress range dengan mengalikan faktor pemberat berupa fraksi pemaparan masing-masing stress range. Kegagalan terjadi jika cumulative damage ratio $D$ lebih besar atau sama dengan satu. Harga $D$ bisa dihitung sesuai Persamaan 6.

$$
D=\sum_{i=1}^{k}\left(\frac{n_{i}}{N_{i}}\right)
$$

dimana $n_{i}$ adalah jumlah siklus tegangan pada blok $i$ dan $N_{i}$ lifetime untuk tegangan blok $i$ dan $k$ adalah jumlah blok tegangan yang bekerja pada struktur.

\subsection{Analisis Keandalan Struktur}

Keandalan struktur didefinisikan sebagai peluang struktur untuk memenuhi tujuan perancangannya dalam kondisi tertentu [1]. Untuk memperkirakan keandalan suatu struktur diperlukan perhatian terhadap setiap bentuk kegagalan yang mungkin terjadi. Ada banyak moda kegagalan yang mungkin terjadi suatu struktur, misalnya kegagalan material, stabilitas struktur, defleksi, kelelahan, dan kita dapat menentukan keandalan struktur secara terpisah untuk setiap moda kegagalan.

Adapun metode yang digunakan dalam penelitian ini adalah metode mean value first order second moment. Metode ini lazim dipakai dalam analisa keandalan struktural [2]. Efek 
pembebanan dan kekuatan struktur yang dinyatakan dalam sebuah fungsi kinerja komponen diperlakukan sebagai parubah-perubah acak.

Dalam metode ini masukan yang diperlukan dalam perhitungan adalah harga rata-rata (mean value atau first moment) dan simpangan baku (standard deviation atau second moment) dari perubah-perubah acak tersebut. Jadi distribusi atau fungsi kerapatan peluang perubah-perubah tersebut tidak diperlukan secara langsung.

Jika $Z$ adalah sebuah random variabel yang menyatakan beban yang bekerja dan $S$ adalah sebuah random variabel yang menyatakan kekuatan material maka safety margin (M) ditentukan sebagai $M=S-Z$ [3]:

Kegagalan akan terjadi apabila beban $\mathrm{Z}$ yang bekerja melebihi kapasitas ultimate $\mathrm{S}$, dengan demikian $\mathrm{M}$ akan benilai negatif. Oleh karena itu peluang kegagalan $P_{f}$ adalah:

$$
P_{f}=P[M \leq 0]=F_{m}(0)
$$

Jika beban $Z$ dan kekuatan $S$ merupakan variabel bebas maka harga rata-rata $\left(\mu_{m}\right)$ dan varian $\left(\sigma_{m}^{2}\right)$ dari safety margin $(M)$ adalah:

$$
\begin{aligned}
& \mu_{m}=\mu_{s}-\mu_{z} \\
& \sigma_{m}^{2}=\sigma_{s}^{2}-\sigma_{z}^{2}
\end{aligned}
$$

Standarisasi $G$, yang mempunyai nilai mean nol dan sebuah standar deviasi, dapat dituliskan sebagai

$$
G=\frac{M-\mu_{m}}{\sigma_{m}}
$$

Kegagalan terjadi saat $M \leq 0$. Jadi persamaan di atas dapat ditulis sesuai Persamaan 10.

$$
P f=P_{m}(0)=F_{G}\left[\frac{-\mu_{m}}{\sigma_{m}}\right]=F_{G}(-\beta)
$$

dan Persamaan 9 dapat ditulis

$$
G=\frac{-\mu_{m}}{\sigma_{m}}=-\frac{\mu_{s}-\mu_{z}}{\sqrt{\sigma_{s}^{2}+\sigma_{z}^{2}}}
$$

dimana $\beta=\mu_{m} / \sigma_{m}$ adalah indeks keamanan (safety index), yang merupakan invers dari koefisien variasi dari safety margin. Dari hasil sebelumnya dapat di generalisasi dengan cara menentukan fungsi keadaan batas $g(x)$ terlebih dahulu:

$$
M=g\left(x_{1}, x_{2}, \ldots, x_{n}\right)
$$

dimana $x_{i}$ adalah variabel acak. Keadaan batas yang diijinkan agar tidak terjadi kegagalan adalah:

$$
M=g\left(x_{1}, x_{2}, \ldots, x_{n}\right) \leq 0
$$

Fungsi keadaan batas ini bisa dikembangkan dengan Taylor's series, dan jika hanya ordo pertama yang kita ambil maka didapat:

$$
\begin{aligned}
g\left(x_{1}, x_{2}, \ldots, x_{n}\right)= & g\left(x_{1}^{*}, x_{2}^{*}, \ldots, x_{n}^{*},\right) \\
& +\sum_{i}\left(x_{i}-x_{i}^{*}\right)\left[\frac{\delta g}{\delta x_{i}}\right]
\end{aligned}
$$

dimana $x_{i}^{*}$ adalah titik linearisasi (linearisation point), dan turunan parsial dievaluasi dititik ini. Pada metode MVFOSM titik linearisasi di tentukan pada nilai mean $\left(x_{1}, x_{2}, \ldots, x_{n}\right)$. Mean dan varian dari $M$ didekati dengan :

$$
\begin{gathered}
\mu_{m} \cong g\left(\bar{x}_{1}, \bar{x}_{2}, \ldots, \bar{x}_{n}\right) \\
\sigma_{m}^{2} \\
\cong \sum_{i}\left(\frac{\delta g}{\delta x_{i}}\right)_{\bar{x}_{i}}^{2} \sigma_{x_{i}}^{2} \\
+\sum_{i} \sum_{j}\left(\frac{\delta g}{\delta x_{i}}\right)_{\bar{x}_{i}}\left(\frac{\delta g}{\delta x_{j}}\right)_{x_{j}} \rho\left(x_{i}, x_{j}\right) \sigma_{x_{i}} \sigma_{x_{j}}
\end{gathered}
$$

dimana $\rho\left(x_{i}, x_{j}\right)$ adalah koefisien korelasi variabel dan $\bar{x}_{i}, \bar{x}_{j}$ adalah mean dari tiap variabel.

$$
\rho\left(x_{i}, x_{j}\right)=\frac{\operatorname{Cov}\left(x_{i}, x_{j}\right)}{\sigma_{x_{i}} \sigma_{x_{j}}} \quad i \neq j
$$

Untuk menilai penyebaran apakah besar atau kecil akan sangat sulit, akan lebih objektif jika diukur relatif terhadap nilai sentralnya yaitu koefisien variasi (COV), dan diberikan dengan persamaan berikut [10].

$$
\operatorname{COV} x=\frac{\sigma_{x}}{\mu_{x}}
$$

dimana $\mu_{x}$ adalah nilai rata-rata (mean) dari tiap variabel, dan $\sigma_{x}$ adalah standar deviasi tiap variabel, dan dirumuskan sebagai berikut:

$$
\mu=\frac{\sum_{i}^{N} x_{i}}{N}
$$




$$
\sigma=\sqrt{\frac{\sum_{i}^{N}\left(x_{i}-\mu\right)^{2}}{N}}
$$

Akurasi dari persamaan di atas tergantung pada pengaruh dipenggalnya orde yang lebih tinggi dari persamaan. Jika variabel $x_{i}$ adalah variabel bebas maka :

$$
\sigma_{m}^{2} \cong \sum_{i}\left(\frac{\delta g}{\delta x_{i}}\right)_{\bar{x}_{i}}^{2} \sigma x_{i}^{2}
$$

Sebagai contoh, jika batas $M$ dinyatakan dengan dua variabel $S$ dan $Z$ maka:

$$
M=g\left(x_{1}, x_{2}\right)=g(s, z)=S-Z
$$

Metode ini disebut sebagai MVFOSM karena linearisasi fungsi batas menggunakan tempat pada nilai mean (mean value) dan hanya orde pertama (First Order) dari tailor's series dan yang diambil hanya sampai momen kedua (Second Moment) dari variabel randomnya (mean dan varian) dipakai untuk menghitung keandalan, tidak memakai seluruh distribusi probabilitasnya.

Interprestasi geometrik dapat dilakukan dengan menentukan safety margin $M=S-Z$, dimana $S$ adalah kekuatan material dan $Z$ adalah beban yang bekerja. $S$ dan $Z$ variabel random bebas yang terdistribusi normal dan dapat ditulis dalam bentuk standart

$$
\begin{aligned}
& S^{\prime}=\frac{S-\mu_{s}}{\sigma_{S}} \\
& Z^{\prime}=\frac{Z-\mu_{z}}{\sigma_{z}}
\end{aligned}
$$

Jika ditentukan safety margin $M=0$ maka $M$ dapat ditulis sebagai

$$
M=\sigma_{S} S^{\prime}-\sigma_{z} Z^{\prime}+\mu_{s}-\mu_{z}=0
$$

Jarak antara titik 0 dan garis $\mathrm{M}=0$ dapat digunakan sebagai ukuran keandalan.

$$
\beta=\frac{\mu_{m}}{\sigma_{m}}=\frac{\mu_{s}-\mu_{z}}{\sqrt{\sigma_{s}^{2}+\sigma_{z}^{2}}}
$$

dan peluang kegagalannya adalah:

$$
P_{f}=\Phi(-\beta)
$$

dimana $\Phi$ adalah fungsi distribusi kumulatif distribusi normal standart (mean $=0$, standar deviasi =1). Transformasi ini biasanya dinamakan standarisasi. Dan harga

$$
\beta=\Phi^{-1}\left(1-P_{f}\right)
$$

diberikan dalam tabel distribusi normal standart.

Untuk prediksi umur lelah struktur kapal digunakan persamaan moda kegagalan sebagaimana pada persamaan (22) dinyatakan sebagai berikut:

$$
M=g(x)=a_{c}-a_{N}
$$

dimana $a_{c}$ adalah panjang retak kritis dan $a_{N}$ adalah panjang retak pada jumlah siklus pembebanan sebesar $N$. Harga $a_{c}$ pada kasus ini dihitung berdasarkan dua hal, yaitu berdasarkan moda kegagalan kepecahan dan moda kegagalan kebocoran. Moda kegagalan kepecahan terjadi jika

$$
K \geq K_{c}
$$

dimana $K$ adalah faktor intensitas tegangan dan $K_{C}$ adalah fractur toughness. Sedangkan moda kegagalan kebocoran terjadi jika

$$
a_{N} \geq t
$$

dimana $t$ adalah tebal pelat alas kapal.

\section{HASIL DAN PEMBAHASAN}

Dalam analisis keandalan umur lelah persamaan kondisi batas kegagalan ditentukan berdasarkan panjang retak kritis. Berdasarkan faktor intensitas tegangan didapatkan bahwa kedalaman retak kritis $a_{c}$ sebesar $71 \mathrm{~mm}$. Sedangkan berdasarkan kriteria kebocoran, kedalaman retak kritis $a_{c}$ sebesar $12 \mathrm{~mm}$. Dari sini dapat dinyatakan bahwa akan terjadi kebocoran lebih dahulu sebelum kepecahan (leak before break), sehingga retak kritis ditentukan sebesar ketebalan pelat.

Persamaan kondisi batas kegagalan dapat ditulis sebagai berikut :

$$
\begin{gathered}
g(x)=t-\left[\frac{(2-m) C(\alpha \Delta \sigma \sqrt{\pi})^{m}}{2(1-R)^{0,5}}\left(N_{f}\right)\right. \\
\left.+a_{0}\left(\frac{2-m}{2}\right)\right]^{\left(\frac{2}{2-m}\right)}
\end{gathered}
$$

dimana $a_{0}$ adalah retak awal dan $N_{f}$ jumlah siklus beban.

Dari hasil perhitungan momen bending akibat gelombang di dapatkan data rata-rata stress range 
sebesar 25,63 MPa dan COV sebesar 0,416. Retak awal diasumsikan rata-rata sebesar $0,5 \mathrm{~mm}$ dengan $C O V$ sebesar 1 . Konstanta perambatan retak $C$ rata-rata sebesar $6,12 \times 10^{-15}$ dengan $C O V$ sebesar 0,5. Adapun variabel yang lain dianggap sebagai variabel deterministik. Data variabel bisa dilihat pada Tabel 1.

Tabel 1. Data Variabel Untuk Perhitungan Keandalan Struktur

\begin{tabular}{|c|c|c|c|c|}
\hline No & Variabel & Notasi & $\begin{array}{c}\text { Mean } \\
(\mu)\end{array}$ & $\mathrm{COV}$ \\
\hline 1 & Stress Range & $\Delta \sigma(\mathrm{MPa})$ & 25.63 & 0.416 \\
\hline 2 & Retak Awal & $a_{0}(\mathrm{~mm})$ & 0.5 & - \\
\hline 3 & $\begin{array}{l}\text { Konstanta } \\
\text { perambatan } \\
\text { retak }\end{array}$ & $C$ & $\begin{array}{c}6.12 \mathrm{e}- \\
12\end{array}$ & 0.5 \\
\hline 4 & $\begin{array}{l}\text { Konstanta } \\
\text { perambatan } \\
\text { retak }\end{array}$ & $M$ & 3.36 & - \\
\hline 5 & $\begin{array}{l}\text { Faktor } \\
\text { geometri } \\
\text { retak }\end{array}$ & $\alpha$ & 1.12 & - \\
\hline 6 & Mean Stress & $\sigma_{m}(\mathrm{MPa})$ & 47.81 & - \\
\hline 7 & Tebal Pelat & $t(\mathrm{~mm})$ & 12 & - \\
\hline 8 & $\begin{array}{l}\text { Ketangguhan } \\
\text { retak material }\end{array}$ & $\begin{array}{l}K_{C} \\
\left(\mathrm{MPa} \cdot \mathrm{m}^{0,5}\right)\end{array}$ & 102 & \\
\hline
\end{tabular}

Dengan memasukkan nilai semua variabel dan distribusi variabel maka akan didapatkan nilai indeks keandalan $(\beta)$, nilai keandalan $(\%)$, untuk tiap-tiap jumlah siklus pembebanan $(N f)$.

Untuk menyatakan umur lelah dalam besaran tahun bisa digunakan persamaan sebagai berikut

$$
U_{t h}=\frac{N_{f} T_{w}}{P_{e} \times 3,1536 \times 10^{7}}
$$

Dimana $U_{t h}$ adalah umur lelah dalam tahun, $T_{w}$ periode gelombang dalam detik dan $P_{e}$ adalah waktu pelayaran efektif dalam persen. Dalam kasus ini $T_{w}$ sebesar 3,78 detik dan $P_{e}$ diasumsikan sebesar $80 \%$.

Kondisi batas kegagalan adalah terjadinya kebocoran pada pelat alas kapal atau panjang retak permukaan sama dengan tebal pelat alas. Dengan kondisi batas tersebut didapat data keandalan struktur kapal sebagaimana pada Tabel 2.

Tabel 2. Pengaruh Jumlah Siklus Pembebanan Terhadap Keandalan Struktur Kapal

\begin{tabular}{cccc}
\hline No & $\begin{array}{c}\text { Jumlah } \\
\text { Siklus }\end{array}$ & $\begin{array}{c}\text { Indeks } \\
\text { Keandalan }\end{array}$ & $\begin{array}{c}\text { Keandalan } \\
(\%)\end{array}$ \\
\hline 1 & $1.0 \times 10^{8}$ & 5.53 & 100 \\
2 & $1.2 \times 10^{8}$ & 3.65 & 99.98 \\
3 & $1.4 \times 10^{8}$ & 2.26 & 98.81 \\
4 & $1.6 \times 10^{8}$ & 1.28 & 90.03 \\
5 & $1.8 \times 10^{8}$ & 0.63 & 73.67
\end{tabular}

\begin{tabular}{llll}
6 & $2.0 \times 10^{8}$ & 0.24 & 59.49 \\
7 & $2.2 \times 10^{8}$ & 0.04 & 51.71 \\
8 & $2.3 \times 10^{8}$ & 0.00 & 50.01 \\
9 & $2.4 \times 10^{8}$ & -0.01 & 49.45 \\
\hline
\end{tabular}

Pada Tabel 2 terlihat bahwa pada siklus pembebanan $1,0 \times 10^{8}$ atau setara dengan operasional kapal selama 15 tahun, nilai indeks keandalan struktur kapal adalah sebesar 5,53 atau keandalan $100 \%$.

Pada siklus pembebanan $1,2 \times 10^{8}$ atau setara dengan umur kapal 18 tahun, nilai indeks keandalan turun menjadi 3,65 atau keandalan $99,8 \%$.

Semakin lama waktu operasional kapal semakin turun indeks keandalannya. Pada tahun

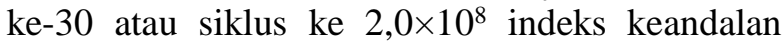
turun menjadi 0,24 atau keandalan $59,49 \%$. Artinya pada tahun ke-30 ini peluang terjadinya kebocoran pada pelat alas akibat lelah adalah sebesar $40,51 \%$.

Jika dilakukan perhitungan dengan variabel deterministik, maka umur lelah struktur kapal adalah sebesar $2,3 \times 10^{8}$ siklus atau setara dengan operasional kapal selama 36 tahun. Pada masa ini keandalan struktur adalah sekitar 50\%.

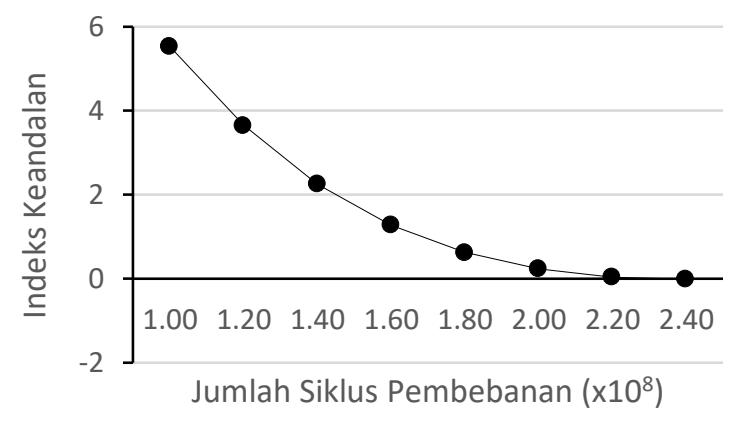

Gambar 1. Kurva indeks keandalan

Penurunan indeks keandalan secara jelas bisa dilihat pada gambar 1. Tiap kenaikan waktu operasional 3 tahun atau $2,0 \times 10^{7}$ terjadi penurunan nilai indeks keandalan rata-rata $62.35 \%$. Penurunan indeks keandalan ini juga bisa diartikan adanya kenaikan resiko terjadinya kegagalan struktur.

Setelah tahun ke-18 perlu dilakukan inspeksi retak pada pelat alas di sekitar tengah kapal. Hal ini untuk menghindari terjadinya kebocoran saat kapal beroperasi. Dari perhitungan memang kedalaman retak belum mencapai ketebalan pelat, tapi kemungkinan retak tersebut sudah merambat dan sudah bisa terdeteksi oleh peralatan inspeksi. Jika ditemukan adanya retak maka perlu dilakukan replating pada pelat tersebut. 


\section{KESIMPULAN}

Dari uraian pada bab pembahasan dapat disimpulkan bahwa Kapal Tanker 17.500 DWT yang beroperasi di perairan Masalembo dari segi struktur dapat dinyatakan cukup andal sampai tahun operasional ke-18 dengan tingkat keandalan 99, $8 \%$. Sampai tahun ke-18 ini resiko kebocoran akibat kelelahan sangat kecil, yaitu sekitar $0,2 \%$. Pada tahun-tahun berikutnya perlu dilakukan inspeksi retak pada pelat alas sekitar tengah kapal, untuk menghindari terjadinya kebocoran. Pada tahun ke-18 dari operasional kapal ini memang belum terjadi kebocoran, tetapi mungkin saja terjadi retak yang kedalamannya belum mencapai ketebalan pelat. Jika dalam inspeksi ditemukan retak pada pelat alas maka perlu dilakukan replating pada pelat alas tersebut.

\section{DAFTAR PUSTAKA}

[1] P. Thoft-Christensen and Y. Murotsu, 1986, Berlin: Springer-Verlag, Application of Structural System Realibility Theory.

[2] D. Rosyid and Mukhtasor, Pengantar Rekayasa Keandalan, Surabaya: ITS Press, 2002.

[3] SSC-351, An Introduction to Structural Realibility Theory, New York: Ship Structure Commitee, 1990.

[4] P. Honarmandi, "Reliability Based Structural Optimization with Fatigue Crack Initiation Constrain," Dissertation Publishing, Toronto, 2007.

[5] Z. Liu, Y. Zhang and W. Wang, "Fatigue Life Reliability Based Design Optimization for The Missile Suspension Structure," Multidiscipline Modeling in Material and Structure, vol. 8, no. 1, pp. 120-129, 2012.

[6] O. Hughes, Ship Structural Analysis Design, New Jersey: The Society of Naval Architechts and Marine Engineers, 2010.

[7] R. Bhattacharyya, Dynamics of Marine Vehicles, New York: Jhon Wiley \& Son, 1978.

[8] J. Barsom and S. Rofle, Fracture and Fatigue Control in Structure, 1987.

[9] G. Dieger, Mechanical Metallurgy, Singapore: McGraw-Hill Book Company, 1988.

[10] A. Rumiati, Konsep Peluang dan Statistika dalam Rekayasa, Surabaya: ITS Press, 1998.

[11] B. Ayyub and G. Souza, Realibility Based Methodology for Life Prediction of Ship 